\title{
Community life in Colombia under the surveillance of extreme right paramilitary organizations.
}

\author{
Dominique Perault1
}

\begin{abstract}
This article examines the ways in which surveillance mechanisms implemented by the paramilitaries (AUC) in certain regions of Colombia have contributed to the establishment of specific forms of social interactions. The aim of this paper is to explore the ways in which the permanent surveillance to which the population is subjected, conditions the ways that people establish contact and communicate with one another, and undermines the construction of the stable references necessary for community life
\end{abstract}

\section{Introduction}

Since the 1950s, extreme leftist groups have sought to bring about a revolution in Colombia by violent means (Pizarro, 1996). In various regions of the country guerrilla groups succeeded in consolidating control. In these areas a part of the population was sympathetic to these groups, perceiving their presence as a way of imposing order on communities where there was no institutional presence (Jaramillo, 1986; Garcia, 1996). In the 1980s, social organization in these areas was altered by the appearance of extreme right wing armed groups backed by major coca cultivators, landowners and the State, which targeted these areas for their armed campaigns (Ranger, 2005). The aim of these right wing groups was not to seize power, but rather to recuperate territory occupied by the guerrilla by means of force. The actions of these paramilitaries were directed against the civilian population identified as the base of support for revolutionary ideology (Pécaut, 2001). Through extreme violence and with financial backing from the cocaine trade, these organizations took control of large areas of the country.

For several decades now, these extreme left and right wing groups have conducted an open and bloody war for control of territories considered to be strategic (Romero, 2003). With time this has lead to the delimitation of geographical areas considered to belong to one armed group or the other. Within these areas each organization guarantees its control by establishing a specific

\footnotetext{
1 EHESS, Paris .
} 
social order. This order is achieved through coercion and oppression of behaviours and forms of expression, by means of a surveillance mechanism designed to reveal the enemy within. The enemy here means those that oppose the established order. The Caudal region provides a noteworthy example of the specific social realities created by organized violence. For several decades this region has been dominated by open conflict, aimed at securing a monopoly of power. From the mid 1970s onwards this region was dominated by four armed groups of the extreme left. From the late 1980s onwards it has been the scene of massacres, disappearances, targeted assassinations and forced displacement of the population, under the almost complete control of paramilitary organizations (AUC).

The aim of this article is to demonstrate how the surveillance mechanism used by the paramilitaries in the Caudal region is the tangible manifestation of their power, enabling them to exercise control over the population (Foucault, 1976). Due to the clandestine nature of these organizations and internal security matters, this mechanism is not visible. In such an area one does not see uniformed paramilitaries patrolling the neighbourhoods, nor any physical installations that might provide evidence of the surveillance mechanism. Instead, this mechanism relies on a network of people dressed in civilian clothes, indistinguishable from other inhabitants, who monitor the development of the community. The purpose of this surveillance is not so much to identify a specific individual, but rather to monitor the population as a whole for behaviours that might represent a threat to the established order. This collective Surveillance is anonymous and thus intangible. Everyone is subjected to surveillance, yet no one is able to identify exactly who is responsible for this. The nature of this mechanism makes it difficult to negotiate when it comes to forms of behaviour perceived as suspicious. In areas like this any stranger is immediately intercepted, interrogated and often eliminated.

This article shows how the mechanism designed to detect the enemy within the population imposes the social order established by the paramilitaries (AUC). The power exercised by these organizations is based on a direct relation to life, since it is a power that can kill (Agamben, 1995). This submission of life to lethal power generates special conditions that influence social relations. Knowing that they are being monitored has led the population to establish special forms of communication to avoid this risk to life. At the same time, the threat that hangs over them leads to distrust of strangers and of neighbours. This distrust transforms each member of the population into a vigilante and thus a guarantor of the established order. From this we can observe that social cohesion within the community is not defined by a common ideological enemy, but instead is based on the perceived danger that one member represents to another. In order to live in such a community a person first of all needs to be aware that their life is permanently at risk.

\section{Methodology to be applied in the context of war}

For my fieldwork I looked for a region with the features that would allow me to observe the social realities that become established in the presence of paramilitaries. It needed to be an area where there has been a constant and stable presence of armed groups of the extreme right, and in which such a presence has promoted the establishment of a specific surveillance mechanism. 
It also had to be a region within which I could travel autonomously, in order to maintain a position of neutrality. This meant that I could not be associated with any NGO, since these are considered by the armed groups to be 'spies' that will denounce their violent actions against the civil population. Being associated with an NGO would have meant being identified as an informer, and this would have polarized all of the information I received. Those who control the region would have concealed their actions, while the civilian population under their surveillance would have found it difficult to talk. In this context, my fieldwork would have been no more than a reflection of the already well-known points of view of the NGOs and these would have gone unchallenged due to people's silence on the issue.

What I needed, in order to be able to travel independently, was a region in which paramilitary control was not too evident. I was interested in the Caudal region because it represented an advanced phase of consolidation of military, political and economic power by the paramilitaries. The presence of just one armed group in this region during more than a decade means that the surveillance mechanism is more flexible, less evident and more difficult to identify; people "seem" to be less afraid of reprisals. Here there is not such a feeling of being watched, and one can be more easily confused by appearances. However, entering this apparently peaceful region without an intermediary is not a practical possibility. Travel within this region requires the support of someone who is publicly acknowledged. For the armed groups, such public visibility is a reliable guarantee, provided through their network of friendships. Once contact had been established, the next issue was how to justify my presence, since people in the region are extremely discrete in matters relating to paramilitary activity. For this reason, the person who facilitated my contact with the group suggested that I should not reveal the specific nature of my research, but instead to talk about it in general terms, as a study of the current situation in the country. This felt rather like telling everything, and yet saying nothing at the same time. In this way my work would be less compromised than it would have been, had I mentioned 'paramilitaries' or 'war', words people here do not use, or at least try to avoid using.

On my arrival in Caudal (pop. 400,000), my objective was to find a neighbourhood where I could carry out my research. One of my contacts suggested that I work with a group of displaced women living in a poor, outlying neighbourhood. Amongst other things, this neighbourhood received a large displaced population from many different parts of the country, as well as being home to a number of people directly involved with the paramilitaries. My first meeting with this community made me aware of the need for an appropriate methodology for my study. I would not be able to ask people directly about their lives, about armed groups, violence or surveillance mechanisms; doors would have been closed to me and both their lives and mine would have been endangered. First I needed to find out what could be said and how these subjects could be approached. To this end I started by simply positioning myself as observer of this new reality.

My first contact with the community quickly showed that, in this context of permanent surveillance, rumour is the central vehicle through which people talk about community life, and that the sources of these rumours are never disclosed for fear of reprisal. Eventually, through listening to these 'rumours', I began to perceive the paramilitary presence in the neighbourhood evident in people's everyday conversations and interactions. This paramilitary presence might be 
seen through a series of anecdotes over lunch, while watching the sunset or when listening to music. Rumour was the narrative form through which their presence was acknowledged and circulated in the public arena.

In order to conduct my fieldwork, I needed to consider rumour (Shibutani, 1966) as a valid means of communication of what was happening in the neighbourhood. My methodology was to hold lengthy conversations with the residents. In these conversations I did not attempt to talk about paramilitaries, but rather observed how this topic arose through dialogue and everyday situations. Talking about daily events in the community made people feel easier with my presence, and avoided exposing them to danger. It is important to mention that during the three months I spent in the neighbourhood conducting my research, I was also the subject of observation and surveillance (Kemple and Huey, 2006). I had anticipated this problem, and took the precaution of making my presence known to the political leaders of the neighbourhood and to the watchmen, with the objective of letting everyone in the neighbourhood know who and where I was. I was under no illusion that this would reduce the amount of surveillance to which I was being subjected. As I was also being watched, I became a part of my own study.

\section{Surveillance Mechanisms employed by the Paramilitaries}

Paramilitaries have been present in this neighbourhood since 1994, when they first appeared in the region. Control of this neighbourhood by the organization has involved various distinct mechanisms. First, was what is known as "liberation". The objective here was to "liberate" the area from the extreme left wing groups that had made it their base for organizational and military operations since the 1980s. Liberation means the physical elimination of any person suspected of belonging to, working for, or sympathizing with the guerrilla, cleansing the area and leaving it free from enemy presence.

Once this first phase was completed, the second objective of the organization was to establish control of the area. For this, a second mechanism was employed; surveillance of external boundaries. First the area was strategically occupied, with the implementation of a security cordon. Key physical positions were occupied. The location of this neighbourhood on the outskirts of Caudal makes Tamane a strategic point in terms of security for the city. This is the first neighbourhood one reaches when approaching the city from the South. This means that anyone travelling to the city from the adjacent areas arrives first in Tamane. Thus it became a refuge for people escaping from other areas and a hiding place from which people could move on to other areas of the city with less chance of being seen. Due to its strategic position, for the armed group this neighbourhood is important as a place from which to observe and control their adversary. The surveillance mechanism consists in positioning men from the organization where they can control entry to the city. The paramilitaries mainly position themselves in a semi-circle around the entry and exit points of Tamane, as with all the other neighbourhoods of the city, Using the political and social networks of all the neighbourhoods in Caudal, the paramilitaries have extended this mechanism from the South to the North of the city, and in all the intervening neighbourhoods, and this has apparently worked effectively. 
Once control of the external boundaries has been established, the organization goes on to establish control within the community through surveillance of the inhabitants. This objective involves a highly complex internal surveillance mechanism. A system of networks is used to guarantee its effectiveness. One part of this mechanism consists of informers, militiamen and combatants, all directly related to the armed group; these provide the main base of support within the neighbourhood. The aher part consists of people who maintain links with the organization in one way or another. These are the local political leaders, paid watchmen, the armed forces and the police.

These distinct public figures work together closely through a secret surveillance mechanism. The Colombian armed forces are important actors in the social organization of the community, and their interventions vary depending on the situation. In the case of youths on street corners consuming using drugs, intervention is initially indirect. A first warning is delivered via community leaders or watchmen. In this first warning the youths are told to stop their criminal activity. If this warning is not heeded two more verbal messages are sent. After a third warning, the youth, or youths in question are taken away for a few days to teach them a lesson, or otherwise simply be eliminated. People report that some nights men arrive in the neighbourhood in a large car and shoot at youths on street corners. According to rumour, these men appear to be members of the military intelligence service. Thus people avoid hanging around in such places, and especially avoid the company of youths considered to be problematic.

Interventions by the armed forces also occur directly. In response to an alert relating to the presence of leftist extremists or any especially serious problem, soldiers are deployed on the main streets, where they stop and search people. The objective is to check for illegal weapons and check identity cards. Anyone without his papers in order is detained at the military base. The community police work in collaboration with the armed forces. The work of this police force involves dealing with problems in the community. They patrol on bicycles in groups of two or three. As with the armed forces, they work closely with community leaders, participating in the organization of social and cultural events and generally supervising the neighbourhood.

Another group that participates in the internal surveillance mechanism instituted by the paramilitaries is the Junta de Acción Comunal (JAC) [Community Action Committee]. This group supervises the political, social and cultural life of the neighbourhood, and also security. They monitor any suspicious activity in the area. The members of the JAC work together with the local population. Public events can be especially useful for providing information. If someone is suspected, an intelligence exercise, known as a "seguimiento" (follow-up) is performed. This involves obtaining as much information as possible about the suspect, but without arousing suspicion. The person may be visited from time to time, neighbours are questioned, and the person's movements are monitored.

The JAC works closely with the Frente de Seguridad (Security Front), which is composed of people who live in the neighbourhood; this group constitutes one of the key civilian security mechanisms. The group was born out of the necessity to monitor the community at a time when, according to inhabitants of Tamane, the neighbourhood was threatened by gangs of youths fighting for control. The appearance of these Frentes coincided with what people generally call 
social cleansing; in other words, the elimination of anyone causing problems in the neighbourhood. The Frenteros (as these watchmen are known) each operate in one specific sector during the whole night. Their principal objective is to prevent robberies and also intervene in family or neighbourhood disputes. Their work, however, is linked to the maintenance of order established by the dominant armed group. Their main role is in providing information about people and occurrences in the neighbourhood. They inform members of the organization and the authorities about any suspicious activity. They know who the potential troublemakers are and keep an eye on them. They also participate in the recruitment of new members for the paramilitary organization. The Frenteros know the names and the number of youths that join the ranks of the armed organization each month.

\section{Rumourasa means of communication}

The informal and formal security networks between all the armed actors involved which constitute the surveillance mechanisms are far from being visible, as one might imagine. They are always present, but unseen. There is no material evidence of the paramilitary or the surveillance he practices. Such invisibility is more surprising when we consider that in every street there is at least one person who maintains a direct relationship with one of the armed groups. People know them, as neighbour, friends of their children or husband, as a neighbour they have grown up with, as a client. However, this same person, as part of the AUC, might be their murderer, or responsible for their displacement, or for the death of a neighbour in a different region of the country, or indeed in the neighbourhood. People know about them, but act as if they do not, as if they were invisible or nonexistent. No one says anything openly. This same attitude is adopted by the paramilitary and by those who maintain formal and informal links with him. His anonymity is preserved in public - people say that he 'works'. He knows that other people know about him, but he ignores this. In the same way, other people act like they don't know what kind of work he does. The paramilitary, his family and neighbours disguise his identity. In this way, the civilian population cohabits with the armed actor, victim with victimizer, and everyone acts as though they did not know each other's true identity. It has been observed that the very same paramilitaries who were responsible for displacing a population, have also taken responsibility for their moral and economic welfare. This support may take the form of donations of land or houses, or direct financial support from the AUC for a displaced population. The paramilitaries might also help them organize and mobilise themselves in order to assert their rights as a displaced population. Neither side dares to recognise publicly the identity of the other. This cohabitation of armed actors and civilian population is characterized by the omission of facts and a silence with regard to responsibility and events, and the mechanisms of control and surveillance.

Within this neighbourhood, then, one learns of the paramilitary presence and surveillance through rumour, and also through what people leave unsaid, through their silences. A person can be identified as being a paramilitary through rumours about the way he leaves the neighbourhood and the length of his absence, for example, or his behaviour upon returning. Rumours may report what someone heard him say when he was drunk, or a comment made by someone close to his family. When rumours about the paramilitary and his allies are communicated in public, they are 
disseminated in a special way. First, people check that there is nobody suspicious nearby. They look around discretely and evaluate the situation. Next, they look fixedly at the object or person directly, or indirectly, related to what they are going to say. This serves to indicate the object or person in question to the interlocutor. If circumstances do not allow for this, the object, or person, is identified by lowering the eyes and giving a short description of it, or his, location. For example, "They say the person I am talking about lives in the red house we are about to pass" or "They say a group of men killed a young lad on the corner of this street last night". When talking about the object or person identified, the speaker lowers his voice, his lips barely moving, and speaks in guttural tones. It is difficult to understand what is said. This is done in order to avoid raising suspicion. The third way in which rumours about armed actors are circulated in the public domain removes the organization and its members from any responsibility. The naming of anyone in relation to the organization, either in public or in private, is done in such a way that the speaker does not appear to be referring to him directly. When the object under discussion is the paramilitary organization, one has the impression that the speaker is referring to a kind of entity without members. By this means there is no danger of identifying anyone from the neighbourhood with the organization. However, at times people talk about the causes that led to the appearance of the paramilitary organization, for example the guerrillas, poverty, unemployment and a lack of security. These are factors that, in themselves, are not a public denouncement of the paramilitaries and their presence in the neighbourhood. When talking about the AUC, people employ the third person 'they'. This impersonal and indeterminate form appears to be free from implications for both the speaker and the paramilitaries. It is a generality and, in consequence, difficult to assign to anyone in particular. Lastly, another way of referring to the paramilitaries, without naming them directly, is by omitting the attribute of the phrase (Russell, 1959). For example, someone might say in the presence of a paramilitary with whom they have a problem that "they think can do anything they like because ...", implying membership of the AUC, but the sentence would remain unfinished. The person is never directly identified, even though their identification as a paramilitary would easily have explained their behaviour.

These distinct ways of talking about the presence of paramilitaries in the neighbourhood, reveal the construction of linguistic codes which refer to events without direct reference to the object/subject or its attribute. This allows people to talk without compromising or exposing themselves. Meanwhile, the interlocutor is left to draw his own conclusions about what his informant is saying. This interpretation, however, must be made in silence, the same silence that characterises the speech of the informant, and which lends it an air of unimportance. In the context of constant surveillance, meaning is implicit, everything is implied. Demonstrating any need for explanations means requiring the other person to reveal himself, to reveal his position, and therefore to feel threatened. At the same time, this puts the speaker in a similar situation. If the other person feels that he is being interrogated he will become suspicious and mistrustful. Not understanding what the other person is trying to say means that one does not understand the same codes for communication and thus does not share the common local perspective with respect to the paramilitary presence (Geertz, 1996). 


\section{Mistrust of others}

These specific forms of acknowledging the presence of the AUC in the neighbourhood account for the near invisibility of the paramilitary and the supreme efficacy of the surveillance mechanism, With time, once a system of territorial and population surveillance has been established, it seems almost to work on its own. Both paramilitaries and the civilian population participate in the maintenance of this system. An interesting phenomenon can be observed in Tamane: the population is being watched, yet watches itself at the same time. In this context, the paramilitary is everywhere, and could be anyone. All other people, in this context, remain an unknown quantity, capable of anything. Thus, each inhabitant becomes, in spite of himself, a watchman both within his private sphere and within the public sphere. Vigilance towards the 'Other' guarantees the stability of life-in-community and also the life of the individual. The surveillance mechanism is maintained over space and time by mistrust of the Other.

In Tamane, when people talk about the paramilitaries they take care not to give value judgments, or to give away their position on the issue. People consider carefully what they are going to say and to whom. Mistrust is constantly present in interactions with others. It is the central element around which social relations are constructed. However, this does not mean that there is no place for confidence (Luhmann, 1979) in the neighbourhood. On the contrary, social life here is built upon confidence; for example, the system of credit, personal relationships and work. This confidence, however, works in parallel with mistrust. They go hand-in hand; confidence and mistrust are two sides of the same coin. Confidence between people in the neighbourhood is established only during an immediate exchange with the other person and only for that limited period, and mistrust is never completely put aside.

Most social interactions are subject to well-defined criteria. For example, a conversation with an unknown person will revolve around what the interlocutor has heard people say about him and be affected by suppositions about this person, based on rumour. A meeting with another person is used to obtain confirmation of previous rumours. Instinct also plays an important role. In any context in which identities and subjects are usually hidden, knowledge of the world often comes through feelings. There is little room for argument. Opinion of the other is based on affinity and rumour. This feeling is principally founded on the way in which the other observes his interlocutor; whether the person looks directly back at him or not. Once past this first stage of the encounter, the important thing will be the information that each person manages to obtain about the other. For this reason it is important not to arouse suspicion. To achieve this, the person involved in the interaction must respond calmly to the questions being asked. The more he vacillates in his response, the more the other person's mistrust is increased. The result of this exchange will determine how the rest of the encounter continues. Once a minimal degree of confidence has been established between the two interlocutors, the conversation takes the form of a series of jokes. However, simply talking about things in this way does not in itself confer confidence. It does, however, play a role in the establishment of confidence. It is a kind of test, a chance to measure the other person's power. Normally it is the person in the superior position of power that initiates this exchange. His interlocutor will do no more than test his capacity to keep up the game with each new joke. The jokes, however, do not compromise the person who makes them. Themes related to paramilitaries are avoided. Jokes are more likely to be 
about gender differences. The joke thus constitutes the potential recognition of a common language between two unknown people, as well as creating a common space through which to approach and identify the other. Through the joke, the other can be identified as a person in whom one can have confidence or not.

This exchange can generate goodwill towards the other, allowing a more trusting relationship to develop. However, this confidence is always subject to question. Future encounters will follow the same pattern, though they will be less intense than the first. An attempt will be made to find out more about the other, through more intimate questions about, for example, marital status and where the person lives. However, mistrust is always latent. The interlocutors are always looking for information that will reveal who the other person might really be.

Obtaining such information is not an easy task. However much time may have passed since the first encounter, the truth might always remain hidden. If it is different from perceived current reality, it will only be revealed through gestures, choice of words and involuntary, inappropriate behaviour. If a potentially threatening truth is discovered, goodwill is cancelled. Discovering a new identity for a person immediately erases what others believed and felt about him - what they saw in him previously. And from that moment his life is in danger.

\section{Measuring the powerof the other}

An analysis of the surveillance mechanism used by the paramilitaries reveals two functions external and internal surveillance - which are closely linked. Firstly, the external surveillance mechanism serves to defend the boundaries of the zone in which the organization is implanted. The aim is to impede the penetration of this zone by guerrillas through control of entry and exit points. With its members positioned in key locations, the organization can discover the movements and strategies of its adversary. This external surveillance is then complemented by the internal surveillance of the community, aimed at identifying any of the enemy who may have managed to infiltrate the neighbourhood. This internal surveillance is carried out by members of the armed organization, the institutional armed forces, the community political committee and the watchmen. Both organizations of the extreme right and extreme left use the same means of infiltration, sending their men into enemy territory to carry out intelligence work in order to plan future attacks.

On first sight, identifying enemies of the paramilitaries may appear straightforward. However, in reality, identification is much more complex. The adversary has no fixed ethnic, religious or cultural background, as in other contexts of armed conflict (Zurawski, 2005). In Colombia their background is ideological and social. While it is easy to identify the enemy on the battlefield by badges on their uniforms, it is much more difficult in everyday life. Here the enemy is imperceptible. This characteristic has two sides. Firstly, when the enemy is an informer sent by an enemy organization, his status will be that of an inhabitant of the neighbourhood. He will be just like anyone else, a member of the community in which he lives. His imperceptibility is a strategic military requirement. Thus, for the paramilitaries there is not just one enemy, defined according to ideological criteria. Instead, the enemy is the population as a whole, in other words 
anyone who does not collaborate with them, whether in terms of money, surveillance or respect for the rules laid down by the organization once it has established itself in a particular territory. In this context the enemy is anyone who, through behaviour or gestures, does not participate in the maintenance of the paramilitary order. The imperceptibility of the enemy is due to the fact that all inhabitants are potential enemies. The internal surveillance mechanism exists to uncover and reveal them. In a paramilitary controlled territory the cohesion of the community is not based on the identification of a determined ideological enemy, but on threats and the fear of death that hangs over everyone's head. The population will adhere to the political project of the organization because their only options are collaboration, displacement or death.

We can perceive in the surveillance established by the paramilitaries in the Tamane neighbourhood, the existence of a social space built upon a speculative relationship with an omnipresent enemy. This phenomenon has direct consequences for interactions between members of the community. It leads to the appearance of specific forms of communication in interactions with the other. As a communication mechanism, rumour used to discuss events in the neighbourhood provides a space for things that cannot be said in public for fear of being identified as an enemy of the established order. Similarly, mistrust of others is the principal resource for preserving the life of this community. So we can see how people in this neighbourhood participate, through their attitudes, in the maintenance of the surveillance mechanism established by the paramilitaries. This is not done to protect themselves from any external enemy, but rather to protect themselves from one another.

This rumour with relation to the paramilitary, this permanent mistrust of the other, is closely linked to the surveillance mechanisms established by the paramilitaries. Feeling that one is being watched makes it difficult to construct stable codes for community life. Interactions between inhabitants of this neighbourhood are instead built on an understanding of what the other person can do to you, to whom they might be connected, and how much power they might have over you. Thus we can see that in this context the common social metaphysic is a metaphysic of power (Boltanski and Thévenot, 1991). The constant flux between confidence and mistrust is the concrete manifestation of the absence of a stable legal framework. Confidence depends on the manifestation of consistent evidence which shows that the person in question has passed a series of social tests, and that they can be trusted in the future (Quéré, 2001). In Tamane there are social tests, but these tests do not confer long-term confidence. This means that any interaction can potentially result in loss of life. In this context, violence is not merely symbolic (Bourdieu, 1977). Relations become relationships of violence and of symbolic interaction, and these become completely inseparable. Thus, what people are interested in understanding about the other is their power and its nature and reach. Knowing who someone really is means knowing what kind of threat he represents.

In this context of permanent surveillance, interactions take place on the border between truth and non-truth. It is a place where there is no recourse to any ethical or moral value. By its very nature, this border is precarious and always subject to question. It is a balancing act between 'being' and 'appearing-to-be', between what the other wants to see and what one really is. In this context, we are looking at a power game aimed at discovering who the other really is. This is done by constantly evaluating what he says and the way he says it, any change of behaviour or 
gesture. The other will attentively interpret everything, and everyone knows this. Everyone plays the same game. Thus, people develop gestures, phrases and types of behaviour that are simple but have the power to immediately identify them to others and define them as friend or enemy. This is an indispensable condition for living within this context. The equilibrium between being and appearing-to-be must be maintained; one must be vigilant, never lower one's guard because the other is always there, looking out for any anomaly.

\section{Conclusions}

The current conflict in Colombia can be viewed as an interruption of politics, rather than a continuation of politics by other means, since the objective of the various armed groups is to destroy the enemy. This change in the conflict can be witnessed in the areas controlled by the different groups. Although this article is concerned exclusively with paramilitary groups, different armed groups, operating in other areas, also mobilize against "enemy objectives"; these are not necessarily enemies that manifest open hostility, but rather individuals or populations who have been confirmed as dangerous, independently of their conduct, even if they appear to be friendly (Brossat, 1998). People are classified either as friends who deserve to live or enemies that must be excluded by assassination..

This new turn that the Colombian war has taken has led to a certain homogeneity in the way in which the different organizations guarantee their presence in the territory under their influence. What appears to prevail in such zones is a permanent state of emergency, which these groups use in order to implement their control (Agamben, 2005). As we have seen in the case of the Tamane neighbourhood, the surveillance mechanisms upon which paramilitary control is based are used to isolate the adversary and thus subject the inhabitants to the established order. These mechanisms do not, however, aim to preserve, protect or develop the lives of inhabitants (Foucault, 1975-1976). On the contrary, they serve to crush life, to destroy it. In these territorial spaces the power exercised by these organizations is not used to protect life but rather constitutes an asymmetrical right: power means the right to appropriate life and the privilege of being able to suppress it. Thus, surveillance mechanisms reveal the foundations of the control exercised by the paramilitaries; a control directly related to life, in that this organization is able to kill. Therefore, life is directly related to the exercise of power and is dominated by this relationship. Control can be guaranteed because the right to life is held captive by this power (Agamben, 1995).

Using the Tamane case as an example we have attempted to show the effects on social reality produced by paramilitary control over life. Through fear of assassination, the population is obliged to accept the law of silence and to obey orders. This perpetual state of fear encourages the development of new ideological means by which inhabitants relate to one another and to their social environment. The use of rumour as a means of communication, along with other personal strategies, reveals that people are well aware that paramilitary control is based on the control of their lives. In this way, armed violence is able to install itself within a common space in which social relations become relationships of power. Such a social reality, in which brute force prevails, encourages the emergence of particular social competences which may only be used by 
inhabitants of these kinds of zones. Such social competences develop in response to the real threat that affects every inhabitant, and constitute a resource that may be used again when other armed groups occupy the territory. However, this situation does not permit the construction of stable social relations. On the contrary, it serves on the one hand as a constant gauge for the level of danger that one member represents to another, and thus as a means of guaranteeing survival for the individual; on the other hand, these social competences help to give an air of viability to a reality that is hostile to the construction of community life.

\section{References}

Agamben, G. (1995) Homo sacer, Il potere soverano e la nuda vita. Torino: Editioni Einaudi.

Agamben, G. (2003) Etat d'exception, Homo Sacer. Paris: Seuil.

Boltanski, L. Thévenot, L. (1991) De la justificacion, Les économies de la grandeur. Paris: Editions Gallimard.

Bourdieu, P. (1978) 'Sur l'objectivation participante', Actes de la recherche en sciences sociales 23, septembre.

Bourdieu, P. (1977) 'Sur le pouvoir symbolique', Annales 3, mai-juin

Brossat, A. (1998) Le corp de l'ennemi, hyperviolence et démocratie. Paris: Editions la Fabrique.

Foucault M. ( 1976) Histoire de la sexualité I, La volonté de savoir. Paris: Gallimard.

Foucault M. (1975-1976) 'Il faut défendre la société', Cours au Collège de France, Haute Etudes, Paris : Gallimard/Seuil.

Garcia, C.I. (1996) Uraba, region, actores y conflicto, 1960-1990. Bogota: CEREC.

Geertz, C. (1996) Ici et là-bas L'anthropologue comme auteur. Edition Metailie

Jaramillo E., Mora L., Cubides F. (1986) Colonizacion coca y guerrilla. Bogota: Alianza Editorial Colombiana

Kemple, T \& Huey, L. (2006) 'Observing the Observers: Researching Surveillance and Counter-Surveillance on "Skid Row", Surveillance \& Society 3(2/3) 'Doing Surveillance Studies': 139-157, http://www.surveillance-and-society.org/articles3(2)/observing.pdf

Luhmann, N. (2002) 'Confiance et familiarité, problèmes et alternatives', in 'La confiance', Reseaux 108: 15125.

Pécaut D. (2001) Guerra contra la sociedad. Bogota: Espasa Hoy.

Pizarro L.E. (1996) Insurgencia sin revolucion, la guerrila en Colombia en una perspectiva comparada. Bogota: TM Editores.

Quéré, L. (2002) 'La structure congnitive et normative de la confiance', in La confiance, Reseaux 108: 126152.

Ranger, A. (ed.) (2005) El poder paramilitaria. Bogota: Planeta.

Romero, M. 2003) Paramilitares y autodefensas, 1982-2003. Bogota: IEPRI. 
Russel, B. (1959) Signification et vérité. Paris: Flammarion.

Shibutani, T. (1966) Improvised News: A Sociological Study of Rumor. Indianapolis: Bobbs-Merrill.

Zurawski, N. (2005)' 'I Know Where You Live!" - Aspects of Watching, Surveillance and Social Control in a Conflict Zone (Northern Ireland)', Surveillance \& Society 2(4) 'People Watching People': 498-512, http://www.surveillance-and-society.org/articles2(4)/ni.pdf 